\title{
Youth and Student Slang in British and American English: An Annotated Bibliography.
}

Félix Rodríguez González

Universidad de Alicante

\begin{abstract}
This article contains an annotated bibliography of the slang used by young people, and specifically the slang of students, in both Britain and the United States. In addition, there is a brief account of the English influences on foreign youth slang. Some introductory remarks on the expressive nature of the language of such groups are also made.
\end{abstract}

\section{Introduction}

Slang is an area of lexis in a permanent state of flux consisting of vivid and colorful words and phrases which characterize various social and professional groups, especially when these terms are used for in-group communication. Slang provides and reinforces social identity but it is also used in society at large to achieve an air of informality and relaxation. Because of its nature and the multiplicity of its aims, slang is a meeting point for people working in different fields, lexicologists, sociolinguists, psychologists, and even for the lay public.

However, the study of slang, especially its lexicographic registration, is often overlooked or disregarded, due, in great part, to its ephemerality and the informal, humorous and taboo character of many of its expressions, which leads to the belief that it is a deviation from the standard language.

Of all social groups, the young are the most prone to the use and renovation of slang and unconventional language. They exhibit great social dynamism and are receptive to changes in fashion: in clothes, look, style, and also in speech. They have little political power but they may use slang as a counter-cultural tool, as an arm against established authority and conventions. In our modern and cultivated societies, students constitute one large subgroup within the young which deserves special study, for many a time they 
develop a special kind of vocabulary. As a modest contribution to this area of research, in the present article I have compiled and commented on the bibliography related to the special vocabulary of these two groups in British and American English. Such a restriction on the field of study has led me to try to compile as exhaustive a list as possible, which explains why works of very different approaches and length have been included.

The list can be taken as illustrative and representative of the differences between the range and extension of the slang used by youth and students in Britain and America in the last decades, which immediately leads us to think of differences in their social environments. It is easy to understand that some social groups are more prone than others to creating and using slang. On the whole, Americans are believed to be much fonder than are the British of using informal and unconventional language, as Mencken well pointed out in his American Language. Certainly, there is a large body of general slang which differs noticeably from the British, but in the language used by students these differences are even greater. If slang is said to grow especially in small and somewhat restrained groups, one could argue that daily life of many a student on an American campus, often enclosed in halls and fraternities, helps them to develop a sense of solidarity and to become involved in a similar style of (communal) life. Conversely, the British student, being more integrated in normal living patterns, would tend to favour a more standard language. In this light one could also understand, for example, the paucity of student slang in a country like Spain where, in marked contrast, campus life hardly exists.

One perennial problem in the study of student slang is its differentiation from general slang. In effect, a good number of words and expressions classed as student slang are found to belong to the language of youth and other social groups. Outside the specific technical jargon of students, which is easy to trace and minimal in comparison, and the slang notoriously associated to the physical conditions of their life (housing, college, etc.), the expressive language found in it is very similar in its linguistic devices and motives to the one spoken by their non-student peers, for both groups share the same system of beliefs and are involved in similar communicational practices (drugs, music, fanzines, graffiti, etc.). Although the language of these particular fields is predominantly inspired by youth, it has not been included per se in this bibliography, unless they are associated to a particular youth sociolect.

For the same reason, I also haven't included articles on slang whose content is general in application (for example, the Lighter/Dumas theoretical article, "Is Slang a Word for Linguists?") or dictionaries and glossaries (e.g. Spears, Thorne, etc.) which have registered words coined or used by youth or students. If some lexicographic works of general outlook are listed (for example by Partridge), it is because they contain a section dedicated to the language of these groups. With these provisos-and these limitations-I have compiled the present bibliography.

Since the aim of this bibliography is to provide a useful tool for those who wish to do work in this area, many of the references listed here have been annotated, except in those cases where the titles themselves are sufficiently explanatory. All entries are listed alphabetically, although they have been previously classified under various thematic sections which discriminate between British and American youth and student slang, and general and special-word studies. 


\section{British (and general)}

\section{Youth slang}

Adelman, Clem. "The Language of Teenage Groups." They Don't Speak Our Language. Ed. Sinclair Rogers. London: Arnold, 1976. 80-105. Communicational analysis of the expressive forms of Anglo-American youth groups, with a special reference to teddy boys, traddies, hippies (yippies) and skinheads.

Hudson, Kenneth. The Language of the Teenage Revolution. London: Macmillan, 1980.

Contains glossaries of the new words coined during the 50's and 60's by the British youth. 1983.

. A Dictionary of the Teenage Revolution and its Aftermath. London: Macmillan,

Pei, Mario. The Story of Language. 1952. London: Allen and Unwin, 1966. See ch. 10

"Cant and Jargon," $181-89$, esp. 183-84 and 188-89 on youth slang.

. "Speaking the Queen's Nonglish." Time 24 Oct. 1983: 53. On the language of

some youth tribes.

Widdicombe, Sue and Robin Wooffitt. The Language of Youth Subcultures. London:

Harvester-Wheatsheaf, 1994, $224 \mathrm{pp}$. Contains reference to the way youth subcultures such as punks, gothics, rockers and skinheads construct their identities through the use of language.

\section{Student slang}

[Clarke, Hewson.] Lexicon Balatronicum: A Dictionary of Buckish Slang, University Wit, and Pickpocket Eloquence: Compiled Originally by Capt[ain] Grose and Now Considerably Altered and Enlarged. 1811. 2nd ed. London, 1812.

Cohen, Gerald. “Gussy up 'Dress up': British School Slang Gussy 'Overdressed Person' and Australian gussy 'Affected Man.'" Language and Civilization: Festschrift for Otto Hietsch. New York: Peter Lang, 1992. 94-107.

Gradus ad Contrabrigiam: Dictionary of Terms Academical and Colloquial, or Cant, which are used at the University. Cambridge. 1803.

Marples, Morris. Public School Slang. 1940. Study of the slang of the schoolboy. . University Slang. London: Williams and Norgate, 1950, 187 pp. Extensive study of the slang of British Universities, especially that of Oxford and Cambridge.

Morgan, E. "Wykehamical Notions." Arch. Stud. neu Sprach Litteratur 122.2 (1970): 103-06. Some notes on the student slang of Winchester College, founded by the end of the fourteenth century by W. de Wykeham.

Noble, Celia. “'Weak Speak': An Investigation of Sarcastic Slang." Nottingham Linguistic Circular 6.2 (1977): 21-28.

Nöth, Winfried. "Semiotik der Magie in der Folklore englisher Schulkinder." Grazer Linguistische Studien 23 (1985): 135-47.

Opie, Iona, and Peter Opie. The Lore and Language of School-Children. Oxford: Clarendon P, 1959. Extensive study of the typical language and expressions (jokes, 
riddles, sobriquets, epithets, rhymes, etc.) of primary and secondary schoolchildren in Great Britain (and Ireland) during the years 1951-59.

Partridge, Eric. "Public School and Universities." Slang, To-Day and Yesterday. 1933. London: Routledge and Kegan Paul, 1979. 202-14.

Schmidt, F. A Study in English school-life and school-boy slang, as represented by Kipling's Stalky \& Co. 1908.

Stone, C. R. The Eton Glossary. 4th ed. Eton: Spottiswoode, 1909, 79 pp.

\section{American}

\section{Youth slang}

Angelino, Henry. "The Argot of the American Adolescent." Qtd. in Joyce 0. Hertzler. A Sociology of Language. New York: Random House, 1965. 361n10.

Breva, Manuel and J. I. García Alonso. "The Language of Graffiti in a United States University." Revista Alicantina de Estudios Ingleses 6 (1993): 19-31. A study of various types of word-forming devices in American slang as found in the graffiti of the University of Colorado at Boulder.

Costello, Donald P. "The Language of The Catcher in the Rye." American Speech 34.1 (1959): 172-81. A study of the language of Holden-the main character of the above mentioned novel, by J. D. Salinger-considered as an authentic artistic version of the coloquial and informal speech of American adolescents during the 50's.

Eddins, A. W. "The State Industrial School Boys' Slang.” Round the Levee Ed. Stith Thomson. Texas Folklore Society Publication 1. Dallas: Southern Methodist UP, 1916. 44-46. Slang terms, nicknames, and verbal insults among Texas teenagers.

Danesi, Marcel. "Pubilect: Observations on North American Teen-Ager Talk." The Fourteenth LACUS Forum 1987. Lake Bluff: LACUS, 1988: 433-41. The paper studies the "dialect of puberty" from a purely sociolinguistic perspective by using taped conversations of middle-class teen-agers from the Toronto area. Inspired by the Whorfian hypothesis, the article examines the interconnection of language and thought in adolescents, and sees the emotive, connotative, and socially-coded dimensions of their language as both a reflection and a shape of their (egocentrist) way of looking at the world.

Folb, E. A. Runnin' Down Some Lines: The Language and Culture of Black Teenagers. Cambridge: Harvard UP, 1980. Includes glossary.

Gerber, Theresa Alello. "A Secret Vice: A Study of Private Language and Imaginary Kingdoms in Childhood and Adolescence." Child and Adolescence Social Work Journal 3.3 (1986): 151-60.

Habbe, S. "Nicknames of Adolescent Boys." American Journal of Orthopsychiatry 7 (1937): 371-77.

Hertzler, Joyce O. A Sociology of Language. New York: Random House, 1965. See 305-6; includes comments on the language of adolescents (320-22), soldiers and "hipsters." 
Hyde, James Par. "Rat Talk: The Special Vocabulary of Some Teenagers." The English Journal 71.3 (1982): 98-101.

Lennoy. W.-C. de and E. Masterson. "Teen-Age Hophead Jargon." American Speech 27 (1952): 23-31.

Murray, Thomas. "Recent Teenage Slang: Sike." Comments on Etymology 18.3 (1988): 6-10.

Nelson, Edward A., and Edward Rosenbaum. "Language Patterns Within the Youth Subculture." Merrill-Palmer Quaterly 18.3 (1972): 273-85.

Orgel, S. Z. and J. Tuckman: "Nicknames of Institutional Children." American Journal of Orthopsychiatry 5 (1935): 276-85.

Peterson, M. S. “Totemism in Boyhood Nicknames." American Speech 2 (1927): 476-77.

Student slang: General studies

Abel, James W. A Study of the Speech of Six Freshmen from Southern University (Negro). Diss. Lousiana State U, 1950.

Banchero, Lawrence, and William L. Flinn. "The Application of Sociological Techniques to the Study of College Slang." American Speech 42.1 (1967): 51-57.

Busse, Thomas V. "Nickname Usage in American High School." Names 31-4 (1983): 300-306.

Cameron, P. “The Words College Students Use and What They Talk About." Journal of Communication Disorders 3 (1970): 36-46.

Eble, Connie C. "Slang, Productivity, and Semantic Theory." The Sixth LACUS Forum 1979. Ed. W. C. McCormick and H. J. Izzo. Columbia: Hornbeam, 1980. 215-227. Illustrates the productive processes at work in college slang: semantic changes such as generalization, specialization, amelioration and pejoration; tropes such as metonymy, synecdoche, metaphor, and irony; and processes of word-formation such as clipping, acronymy and rhyming.

. "Slang, Productivity, and Semantic Theory: A Closer Look." The Seventh LACUS Forum. Ed. James E. Copeland and Philip W. Davis. Columbia: Hornbeam, 1981. 270-75. The author provides additional examples-from two semantic areas, destruction and drunkenness-and discusses more fully the theoretical implications of productivity of slang for a theory of linguistic ability.

. "Scenes from Slang." SECOL Bulletin 5 (1981): 74-78. In addition to the ordinary semantic/pragmatic strategies like generalization, metonymy, metaphor, etc., "scenic" (i.e. cultural) information is needed in the creation and understanding of slang.

. "Greetings and Farewells in College Slang." The 9th LACUS Forum. Ed John Morreall. Columbia: Hornbeam, 1983. 433-442. By adopting the notion of "frame" from the field of artificial intelligence, as proposed by M. Minsky (1975), the author examines synchronic semantic motivation of greetings and partings and describes kinds of words and phrases appropriate in these expressions.

. "Slang and Cultural Knowledge." The 12th LACUS Forum. 1985. Eds. Mary C. Marino and Luis A. Pérez. Lake Bluff, 1986. 385-390. The author examines cultural 
allusions of college slang, in particular those found in entertainment areas like television, movies, popular music, and sports.

. "Slang: Etymology, Folk Etymology, and Multiple Etymology." The SECOL Review 10 (1986): 8-15. The paper addresses the difficulties of establishing the etymology of slang items, discussing in particular two processes which seem to loom larger in slang than in the general vocabulary, folk etymology and multiple etymology; e.g. a non "a loser" ( $\leftarrow$ non-entity, non-factor), a quad "clumsy, stupid person" ( $\leftarrow$ quadrangle, quadriplegic, etc.).

."The Subversiveness of Slang," Th 13th LACUS Forum 1986. Ed. Ilah Fleming. Lake Bluff: LACUS, 1987. 477-82. Parting from Halliday's concept of "antilanguage," the paper examines the irreverent edge to slang and argues that college slang is not a full-fledged antilanguage. The opposition to authority is "rather playful and in predictable areas, obligatory and automatic rather than heartfelt - basically serving as another sway for college students to acknowledge their common plight."

"Slang as Poetry," The Fourteenth LACUS Forum 1987. Ed. Sheila Embleton. Lake Bluff: LACUS, 1988. 442-45. The author studies the affinity between slang and poetry by examining the phonology, syntax and lexicon of college slang. Mention is made of oral motivated devices such as rhyme and alliteration, and semantic transformations like metonymy and metaphor.

."The Ephemerality of American College Slang." The 15th LACUS Forum 1988. Eds. Ruth N. Brend and David G. Lockwood. Lake Bluff: Linguistic Association of Canada and the United States, 1989. 457-69. After taking various glossaries of college slang published in the past as a basis of comparison, the author highlights not only the small percentage of forms that have persisted but also the short span of time involved. . College Slang 101. Wilton: Spectable Lane P, 1989, 96 pp. A compilation of slang terms used by students at the University of North Carolina-Chapel Hill during the period 1972-1989. (Reviewed by G. Cohen. The SECOL Review 14 (1990): 191-93, and L. Ashley, Names 38.4 (1990): 373-75.)

"College Slang in the Conversational Structure." The 16th LACUS Forum 1989. Ed. Michael P. Jordan. Lake Bluff: Linguistic Association of Canada and the United States, 1990. 451-59.

."Forms of Address in the Speech of College Students." The 17th LACUS Forum 1990. Ed. Angela Della Volpe. Lake Bluff: Linguistic Association of Canada and the United States, 1991. 483-87. The author points at the frequent and imaginative nature of students' forms of address-which include, among others, attention-getters like man and dude, kinship terms (cuz $\leftarrow$ cousin, bro $\leftarrow$ brother), derogatory nons (butthead, skank), and invented nicknames (Hank for Henry) -and explores their social function. . "Borrowing in College Slang." The LACUS Forum 1991.Ed. Ruth M. Brend. Lake Bluff: Linguistic Association of Canada and the United States, 1992. 505-510. The paper points at the infrequency of borrowings in college slang-fewer than 100 of at least 3,000 separate items-despite these being the greatest source of new words in the documented history of English. After examining a variety of borrowings from different languages, the dialect of blacks is pointed as the most influential. 
“"The Social Functions of American College Slang." International Congress, 1992.

The paper emphasizes the social richness of slang focusing on two subsets of vocabulary, judgments of approval and disapproval and terms that oppose authority.

Gilmer, Paul. "Inventiveness in College Slang." Abstract in Newsletter of the American Dialect Society 19.3 (1987): 7. Discusses word-formation processes and sociolinguistic contexts for creation of new slang, based on five-year study at the University of Texas. Gore, Willard C. Student Slang: Contributions to Rhetorical Theory II. Ed. Fred Newton Scott. Ann Arbor, 1896. Rprt. by Gerald Cohen in Comments on Etymology 22.7 (1993): 1-47.

Hall, B. H. College Words and Customs. Cambridge, 1856. Valuable examples drawn from British Universities as well as from many US colleges.

Kieski, Richard E. A Descriptive Analysis of the Vernacular Lexicon of Black and White Students at Ohio University in relation to Rock Music. Diss. Ohio University, 1978, $187 \mathrm{pp}$.

Kosek, Steven. "Variable Negation in a Fraternity Jargon." Language and Style 9.3 (1976): 192-96.

Kratz, Henry. "What is College Slang?" American Speech 39 (1964): 188-95.

Lederer, Richard. "Prep School Slanguage." Verbatim 9.4 (1983): 1-3. Of students in preparatory school.

Lederman, Marie Jean. "Hip Language and Urban College English." College Composition and Communication 20.3 (1969): 204-14. Suggests that urban college teachers should include student slang in their English composition classes.

Major, Clarence. Dictionary of Afro-American Slang. New York: International, 1970, 127 pp. Extensive dictionary, including some "Southern Negro college slang" of 1940's; it states that black slang stems from "the rejection of the life-styles, social patterns, and thinking in general of the Euro-American sensibility." (Reviewed by R. Abrahams and J. Szwed in American Anthropologist 77.2 (1975): 329-35.)

Meyer, Peggy L. "Slang in the Hallowed Halls of Learning: A Sociolinguistic Analysis." ERIC Document 142 081, 1976, 52 pp. Preliminary survey of problems in collection and sociological analysis of student slang at the University of Virginia.

Olesen, V. and E. Whittaker. "Conditions under which College Students Borrow, Use and Alter Slang." American Speech 43.3 (1968): 222-28.

Poston, Lawrence III. "Some Problems in the Study of Campus Slang." American Speech 39 (1964): 114-23. Compares University of Florida slang with slang at US schools elsewhere.

77-78.

"On the Persistence of Some Older Student Slang." American Speech, 40 (1965):

Reynolds, Horace. "College Words with a Musical Accent." American Speech 29 (1953): 293-94.

Rodríguez González, Félix. "Abbreviations and American Slang." English Today 31 (1992): 39-44. See esp. "The slang of students" 41.

Seymour, Richard K. "Collegiate Slang: Aspects of Word Formation and Semantic Change." Publications of American Dialect Society 51-60 (1969-73): 13-22. Based on a corpus compiled at Duke University in 1964-67. 
Schultz, William Eben. "College Abbreviations." American Speech 5.1 (1930): 240-44. Sparkman, Evelyn P. A Study of High School Slang in Jonesboro, Arkansas. Diss. George Peabody College, 1940, 117 pp. Based on surveys in 1930 and 1940, presents 765 expressions for nicknames, emotions, food and drink, drunkenness, money, disapproval, and other domains.

Todd, Charles Lafayette. "Lingua Collegiensis circa 1850." Verbatim 9.4 (1983): 4-5.

Warnock, Elsie. "Terms of disparagement in the dialect speech of high school pupils in California and New Mexico." Dialect Notes 5.2 (1919): 60-73.

Student slang: Glossaries and particular studies

Allison, Lelah. "M. U. Colloquialisms." American Speech, 16 (1946): 75.

Arnold, J. W. "The Language of Delinquent Boys." American Speech 22 (1947): 120-23.

Slang terms used at the Boys' Industrial School near Lancaster, Ohio.

B., R. R. "More on Rents." American Speech 64.3 (1989): 243. Comments on various uses of the foreclipping rents "parents."

Babbitt, E. H. "College Slang." The Chautauquan 31 (1900): 22-24. . "College Words and Phrases." Dialect Notes 2.1 (1900): 3-70.

[Bagg, Lyman]. Four Years at Yale. New Haven, 1871. Contains a seven-apage list of words from the author's undergraduate years at Yale in the late 1860's.

Bass, Altha Leah. “The University Tongue." Harper's Magazine 144 (1922): 529-30.

Bolwell, R. "College Slang Words and Phrases (from Western Reserve University)." Dialect Notes 4.3 (1915): 231-38.

Boone, Lalia Phipps "Gator (University of Florida) Slang." American Speech 34.2 (1959): 153-57.

Calkin, Nancy, and William Randel. "Campus Slang at Minnesota." American Speech 20-3 (1945): 233-34.

Carr, Dorothy. "Some Annapolis Slang." American Speech 14 (1939): 76-77.

Carter, Virginia. "University of Missouri Slang." American Speech 6.3 (1931): 203-206.

Danton, George. "College English (Oberlin)." American Speech 4 (1929): 420. . "Americana (Oberlin)." American Speech 5 (1930): 281-82.

Daughrity, Kenneth L. "Handed-Down Campus Expressions." American Speech 6(1930): 129-30.

Dickinson, M. B. "Words from the Diaries of North Carolina Students." American Speech 26.3 (1951): 181-84.

Dundes, Alan, and C. F. Porter. “American Indian Student Slang.” American Speech 38.3 (1963): 270-77.

Dundes, Alan, and M. R. Schonhorn. "Kansas University Slang: A New Generation." American Speech 38.3 (1963): 163-77.

Eble, Connie. "Yo, Dude. What's Up." Tar Heel Junior Historian 31 (1991): 42-44.

Edmiston, W. C. A Study of Provincialisms from Northern Todd County, Kentucky. Diss. George Peabody College, 1929. List of 893 unusual words and expressions collected by personal observation and from school children. 
Eikel, Fred, Jr. “An Aggie Vocabulary of Slang.” American Speech 21 (1946): 29-36.

Slang at Texas Agricultural and Mechanical College.

Eisiminger, Sterling. “College Slang 1975.” Verbatim 3.1 (1976): 8. Some current slang expressions collected on the campus of Clemson University, Clemson, South Carolina. Eschholz, Paul A., and Alfred F. Rosa. "Course Names: Another Aspect of College Slang." American Speech 45.1-2 (1970): 85-90.

Farrand, Margaret L. “The Slang at Smith.” The Delineator 97.3 (1920): 119.

Gore, Willard C. "Student Slang." Contribution to Rhetorical Theory II. Ed. Fred Newton Scott. Ann Arbor, 1896.

Hall, B. H. A Collection of College Words and Customs. Rev. ed. Cambridge, 1856. Jackson, James L. "I. Notes on Air Force Academy Language. II. Amelioration of Some Slang Terms: Have Present Teen-Agers Gone Ape or Chicken?" American Speech 36 (1961): 148-49.

Jernagin, Bert, and Fred Eikel, Jr. "North Texas Agricultural College Slang." American Speech 23.3-4 (1948): 248-50.

Jones, Michael. "Soda-Fountain, Restaurant and Tavern Calls." American Speech 42 (1967): 58-63. Glossary and description of the expressive language used in the orders made to waiters of a Kansas cafe by their student customers.

King, Viola. Wha'Hapnin'?: A Dictionary of Terms and Expressions Frequently Occurring in the Informal Speech of Young Black Adults in New Orleans. New Orleans: privately printed, 1974, $17 \mathrm{pp}$. Glossary of expresions from Southern University students, compiled to "provide the teacher of black children a means of familiarizing herself with the language that she is obligated to understand if she wishes to teach them."

Kuethe, J. Louis. “John Hopkins Jargon.” American Speech 7.5 (1932): 327-38.

Lynn, Klonda, et al. "Gringoisms in Arizona." American Speech 24 (1949): 234-36.

McDavid, R. I., Jr. "A Citadel Glossary.” American Speech 14.1 (1939): 23-32. Cadet speech at The Citadel, the Military College of South Carolina.

McPhee, M. C. "College Slang." American Speech 3.2 (1927): 131-33. (Univ. of Nebraska.)

. "Odd Colloquialism (Nebraska)." American Speech 15 (1940): 334-35.

Minton, Arthur. "Olympians, Hurricanes, and Vultures." American Speech 19 (1944):

266-70. Records names of boys' clubs in New York.

Morse, William R. "Standford Expressions." American Speech 2.6 (1927): 275-79.

Montero, George. "Note on Zapped." American Speech 37 (1962): 71.

Munro, Pamela, ed. UCLA Slang: A Dictionary of Slang Words and Expressions Used at UCLA. UCLA Occasional Papers in Linguistics 8. Los Angeles: Department of Linguistics, UCLA, 1989, 94 pp. (Reviewed by Connie Eble, "Lexicon of College Slang." American Speech, 65.1 [1990]: 85.)

Murray, Thomas. "How College Slang is Like the Forty-Eight-Hour Dork Effect." American Speech 66.2 (1991): 220-23. List of terms in current use in Ohio State University during the 1983-1988 period.

"Names of Schoolgirls' Clubs in New York City." American Speech 33.2 (19,58): 29-35. 
Parler, Mary Celestia. "Folklore from the Campus." Arkansas Folklore 8 (1958): 4-9. Includes number of says and proverbs.

Parr, Mary Ellen. “College Slang." Science Digest 38.2 (1955): 33-34. Slang of Lawrence College, Wisconsin.

Pierce, Marving. "Slang at the University of Virginia." Abstract in South Atlantic Bulletin 24.3 (1959): 4. Reports slang vocabulary at University of Virginia consists of 150 items and cites their principal characteristics.

Pingry, Carl, and Vance Randolph. "Kansas University Slang." American Speech 3.3 (1928): 218-21.

Poston, Lawrence, III, and Francis J. Stillman. "Notes on Campus Vocabulary, 1964." American Speech 40.3 (1965): 193-95.

Reynolds, Horace. "College Words with a Musical Accent." American Speech 29 (1954): 293.

Russell, Jason Alms. "Colgate University Slang." American Speech 5.1 (1930): 238-39.

Savage, H. J. "College Slang Words and Phrases from Bryn Mawr College." Dialect Notes, 5.5 (1922): 139-48.

Schullian, Dorothy M. “College Slang.” School and Society 58 (1943): 169-70. Glossary of Albion College, Michigan.

Shidler, John Ashton. "More Stanford Expressions." American Speech 7.6(1932): 434-37. and R. M. Clarke, Jr. "Stanfordiana." American Speech 7 (1932): 232-33.

Sebastian, Hugh. "Negro Slang in Lincoln University." American Speech 9.4 (1934): 287-90.

. "Agricultural College Slang in South Dakota." American Speech 11 (1936): 279-80.

Simmons, Donald C. "Some Special Terms Used in a University of Connecticut Men's Dormitory." American Speech 42 (1967): 227-30.

Spencer, Gillmore. "Current College Slang." Univ. of Virginia Magazine 82 (1926): 16-17. Steadman, J. M., Jr. “A Study of Verbal Taboos.” American Speech 10.2 (1935): 93-103. . "Affected and Effeminate Words." American Speech, 13.1 (1938): 13-18. Words classed by students as affected.

Student Life at Harvard. Boston, 1876.

Tillson, William. "How the Boilmakers Did Not Get Their Name." Midwest Folklore 11 (1961): 105-14.

Underwood, G. N. "Razorback Slang." American Speech 50.1-2(1975): 50-69. Discussion and glossary of slang collected at the University of Arkansas, Fayetteville, in 1970-72.

. "Some Characteristics of Slang Used at the University of Arkansas at Fayatteville." Mid-South Folklore 4 (1976): 49-54.

White, William. "Wayne University Slang." American Speech 30 (1955): 301-5.

. "Whitman College Slang." American Speech 18.2 (1943): 153-55.

Wyllie, John. "Short Dictionary of Slang, Jargon, Cant and Popular Customs Now or Formerly Current at the University of Virginia." University of Virginia Alumni News 24 (1936): 80-81. 


\section{English Influences on Foreign Youth Slang}

French

George, K. E. M. "The Language of French Adolescents." Modern Languages 67.3 (1986): 137-41. See esp. 138.

Schmidt, J. "Phenomenes d'interferences: les emprunts à l'anglais dans le français écrit et parlé en Afrique noire." Cahiers de l'Institut de Linguistique de Louvain 16.2-4 (1990): 139-70. Examines the borrowing of English terms with relation to the use of French in Senegal. A good number of them belong to the slang of students and the one used in the local criminal underworld.

\section{Spanish}

Rodríguez González, Félix "Lenguaje y contracultura: anatomía de una generación." Comunicación y lenguaje juvenil. Ed. F. Rodríguez González. Madrid: Fundamentos, 1989. 135-166. See esp. 153-55.

. "Remarques sur les glissements de sens dans l'argot de la drogue: les anglicismes en espagnol." Cahiers de Lexicologie 64.1 (1994). 147-54.

. "Anglicismos en el argot de la droga." Atlantis, forthcoming.

\section{German}

Fink, H. "Superhit oder Spitzenschlager: Ein Versuch zur Hufigkeit und Funktion von Anglizismen und 'Werbeanglizismen' in deutschen Jugendzeitschriften." Studien zum Einflus der englischen Sprache auf das Deutsche. Ed. W. Viereck. Tübingen, 1968. 185-212.

Tschich, F. "Sit-in, Go-in, Teach-in." Zeutschrift fur deutsche Sprache." 26.1-2 (1970): 37-41.

\section{Finnish}

Loog, Mai. Sanat tyttojen ja poikien puheessa: Tutkimus Tallinnan koululaisten puhekielesta ja slangista ("Words in the Speech of Boys and Girls: A Study of Slang and Spoken Language of Tallinn Youth of Different Age Groups"). Diss. Tampere U Technology (Finland). DAI 54.3 (1993), 670C. Contains reference to Finnish/English loanword use.

\section{Russian}

Potton, F. R. "Expressive Means in Russian Youth Slang." Slavic and East European Journal 24.3 (1980): 270-82. (See esp. 274) 


\section{Serbo-Croatian}

Riffer-Macek, Dora. "Some Marginalia of Language Contact." Studia Romanica et Anglica Zagrabiensia 41-42 (1976): 79-85. On the borrowing of exclamatory and sound imitative English words in the speech of Yugoslav children through the translation of cartoons and comics.

Thai

Owens, Jerry. "Youth Culture in the United States: Some Implications for TEFL." PASAA (Thailand) 19.2 (1989), 50-55. Examines the linguistic influence of the subculture of British and American youth and argues for the introduction of changes in English as a foreign language textbooks in order to avoid a gap between teacher and student usage.

Hausa (and other African languages)

Cooper, M. "Nigerian Schoolboy Slang." Ibadan 11 (1951): 20-21.

Kirk-Greene, A. H. M. "The Vocabulary and Determinants of Schoolby Slang in Northern Nigeria." Journal of African Languages 5.1 (1966): 6-33. See esp. 26-33; for further bibliographic information on the influence of English on African languages, see $26 \mathrm{n} 1$. 